\title{
KNOWLEDGE MANAGEMENT FOR THE INNOVATIVE UNCONVENTIONAL MONETARY POLICY
}

\author{
Silvia Trifonova ${ }^{1}$ and Tsvetana Stoyanova ${ }^{2}$ \\ ${ }^{1}$ Assoc. Prof., Ph.D., Department of Finance \\ ${ }^{2}$ Assoc. Prof., Ph.D., Department of Management \\ University of National and World Economy (UNWE), Sofia 1700, Studentski Grad "Hristo Botev", Blvd. "8 December", \\ Bulgaria
}

\begin{abstract}
The main objectives of the paper are to enhance the knowledge for the innovative unconventional monetary policy of the world's leading central banks, to raise the awareness for this new monetary policy course and to outline the importance of the knowledge management for this important issue. The topic about the innovative unconventional monetary policy is relatively new to the financial theory and practice. The innovation and the originality of this paper are evidenced by the fact that the current study is the first of its kind which is focused on the need of a proper knowledge management for the unconventional monetary policy, implemented by the Federal Reserve (Fed) of the United States, the European Central Bank (ECB) and the Bank of Japan (BoJ). Since the monetary policy of central banks is a major factor for the interest rate changes and in particular, for the government bond yields' changes, an econometric study regarding the impact of the central banks' base interest rates on the central government 10 -year bond yields is undertaken. This is done for a large set of countries, such as the Euro area member states (excluding Estonia), the United States, Japan, China, Russian Federation, Brazil and Turkey. The empirical research covers totally 24 countries during the period 2010-2016 by using monthly data (with totally 84 observations made). The paper can help for creating new scientific knowledge, as the topic of the unconventional monetary policy is up-to-date, innovative, significant and relevant to the international and European research priorities.
\end{abstract}

\section{KEYWORDS}

Knowledge Management, Unconventional Monetary Policy, Global Leading Central Banks, Base Interest Rates, Long-Term Government Bond Yields

\section{INTRODUCTION}

The paper is aimed to enhance the knowledge for the innovative unconventional monetary policy of the world's leading central banks, to raise the awareness for this new monetary policy course and to outline the importance of the knowledge management for this important issue. The topic of the unconventional monetary policy is up-to-date, innovative, significant and relevant to the international and European research priorities. The object of the paper is the knowledge management, and the subject is the unconventional monetary policy of the world's leading banks - Fed, BoJ and the ECB, and its effects on the developed and developing economies. For identifying and assessing the impact of the unconventional monetary policy measures of the reviewed central banks, an econometric modeling is undertaken. It is aimed to assess the impact of the central bank's key (base) interest rates on the central government bond yields. This is done for a set of 24 countries during the period is $2010-2016$ by using monthly data.

The global financial crisis, which started in August 2007 and deteriorated after the collapse of the US investment bank Lehman Brothers in September 2008, deeply affected the financial markets in the developed and developing countries. The crisis was characterized by two main episodes - the mortgage debt crisis in the United States and its transformation into European debt crisis, which culminated with the Greek debt crisis in May 2010. The magnitude of the market turbulences led to a sharp slowdown in the real economic activity, exports collapsed and the global economy plunged into recession. 
In order to respond to the growing economic challenges the world's leading central banks - the Fed, BoJ and the ECB - lowered their key interest rates. The zero lower bound (ZLB) of the nominal interest rates limited the scope for additional easing by lowering the base interest rates. Thus, the leading global central banks shifted the focus from the standard approach of pursuing the inflation and economic growth goals by changing the key interest rates to a wide range of non-standard measures and non-programs that amended the shape of the monetary policy which they conducted before the Great Recession. In the early stages of the crisis the unconventional monetary policy measures were mainly aimed at preventing a collapse of the financial system, and then - to strengthen the financial intermediation. Central banks have taken non-standard monetary measures both in terms of scale and size.

According to Bini Smaghi (2009) the unconventional monetary measures can be defined as a type of policy that is aimed at easing financial conditions. They range from providing additional central bank liquidity to banks to directly targeting liquidity shortages and credit spreads in certain market segments. In general, the unconventional measures directly target the cost and availability of external finance to banks, households and non-financial businesses. These sources of funding may take the form of liquidity provided by the central bank, loans, fixed-income securities or equity.

The policy of lowering the key interest rates below zero was implemented during the period 2012-2016 for the first time in economic history by the central banks of Switzerland, Sweden, Denmark, Japan, and the Euro area (Eggertsson et al., 2018). The unusual measures, known as quantitative easing (or QE), include unprecedented support for the money markets, special credit programs, large-scale asset purchases and preliminary guidance on the monetary policy path. The central banks in the United States, the United Kingdom, Japan and the Euro area stepped up with more clear forward guidance about the monetary policy path and asset purchases. The purpose of the purchases was to lower the interest rates on long-term bonds and to loosen credit conditions. QE has been initiated in order to boost economic growth and demand. In emergency situations, as financial crisis, central banks can impact the quantity of money not only by short-term interest rate changes, but also directly by purchases of financial assets (like government bonds), thus creating new money in the banking system. Central banks also introduced the so-called 'forward guidance' instrument in order to signal the changes in the monetary policy path of keeping interest rates lower for a longer period of time.

The structure of the paper is as follows: Section 2 is focused on the knowledge management for the innovative unconventional monetary policy implemented by the leading global central banks; Section 3 identifies and assesses empirically some effects from the non-standard monetary policy of the ECB, Fed and the BoJ for several large developed and developing economies. These effects are resulting from the empirical study on the impact of the unconventional monetary measures on the long-term central government bond yields in all surveyed countries. The paper concludes with summarizing the results from the study.

\section{KNOWLEDGE MANAGEMENT FOR THE INNOVATIVE UNCONVENTIONAL MONETARY POLICY}

In today's economy, the knowledge has become key success factors for international competitiveness of any organization, in which nonmaterial and intangible values are vital. Companies are witnessing a move on the field of battle from physical resources (capital, raw materials, land, machinery, etc.) in which the intangible resources such as knowledge and ability for managing them have an essential role in the success of the business. Knowledge has become the main source of power, prestige and wealth in the modern economy and society. The generation, acquisition and use of knowledge have become vital for sustainable economic, social and cultural development. This applies both for individuals, organizations, public authorities and companies, and for entire regions and even countries.

When considering what is the knowledge management many questions arise, such as: where to start? What are the organization's goals? What kind of knowledge is needed now and will be needed in the future?

The first step in searching for an answer to those questions is to define clearly the policy for the management of knowledge. In particular, it is very important in the successful introduction of knowledge management for the innovative unconventional monetary policy of the world's leading central banks. As concerns the knowledge management for this type of monetary policy, it should be noted that there is a wide range of means and methods for the management of knowledge. Knowledge management is a new philosophy of management that takes into account the new components of the knowledge-based economy and introduces 
them to the existing and well-developed management tools and approaches or in a completely new management instruments and techniques. Therefore, a clear and profound understanding of the needs and objectives in any organization is needed and it should be in the perspective of the knowledge-based economy. In this case, it is necessary to take into account new areas for creating competitive advantages, public image and credibility.

The category of "knowledge" is a multifaceted, complex, hierarchical and constantly developing. As Massave (2015, p. 8) argues, knowledge is a word long time in use but with the advent of information and communication technologies (ICT) and increased networking, it portrays a new meaning as it is now termed as a resource. There is a variety of definitions of knowledge management that affect different aspects and manifestations of this category. Cyert and March (1963) define knowledge as understanding of causation, which arises on the basis of experience and is stored as in shared mental models and human in the assets, standard procedures rules and traditions in organizations. Devenport (2000) accepts that knowledge is a mix of structured experiences, values, information, that determine the organizational routines, processes, practices and norms. Blackler believes that knowledge is a multi-purpose and complex, sketch, and abstract, and implicitly allocated and individual, physical and mental, expandable and static, verbal and encrypted. Nonaka and Takeuchi (1995), proponents of the Japanese school, argue that "knowledge is not only apparently expressed, and is created in social interactions between the personal and the public".

Because of its fundamental importance, knowledge is often identified with other concepts such as "data", "information", "experience", etc. In order to better understand the processes of knowledge management, it is necessary to distinguish these concepts. To this end, Joia (2000, p. 68) notes the following: (1) "Data" - these are the structured information obtained by measurement, observation, analysis and other cognitive processes, which are presented in a form suitable for storage. The data are the result of a process of structuring the information. (2) "Information" - these are treated with an objective data, lowering the degree of uncertainty of the specific situation. The concept of information only makes sense in the process of transmission from the source to the receiver in the form of messages. (3) "Information resource" - received data which the recipient may use, and thus to check by his experience. (4) "Experience"- this is the information verified in the process of practical activity. Experience is a necessary prerequisite for gaining knowledge. Unit experience is a proven fact. (5) "Wisdom" is the accumulated knowledge, allowing the individual to predict future events. It can be found in the form of intuition. Wisdom is the result of the integration of heterogeneous knowledge and usually gives an answer to the following questions: why, what, how, where, when.

The issue of knowledge management has been firstly introduced in the management science and practice by Karl Wiigsince 1986. But even in the middle of the last century the Nobel Laureate for Economics Herbert Simon began systematically to acknowledge it as the main capital of any organization (Foss and Foss, 2006). In addition, the so-called "popular concept" for the information society is entirely built on knowledge, its management and its use as a basic resource of contemporary social transformations. Bassi (1993) defines that the knowledge management is the process of creating, capturing, and using knowledge to enhance organizational performance, such as documenting and codifying knowledge and disseminating it through databases and other communication channels. According to Allee (2003, p. 64) "knowledge is a state of knowing". This concept has been defined in the knowledge management field as "familiarity, awareness, or understanding gained through experience or study" (Massave, 2015, p. 8). The transferring of knowledge as an aspect of knowledge management has always existed in some form. The widespread use of Internet, ICT and the process of globalization require a different mindset and a completely new management tools, allow encoding, storage, as well as the wide exchange of different types of knowledge. Knowledge management allows the use of this advantage, offering a process for mastering all the knowledge in the organization. Challenge will be to change the thinking of a large number of organizations that adhere to the old ways and forms of governance.

With this regard, the new monetary policy course implemented by the Fed, BoJ and ECB, represents a clear example for an innovative, fundamental and challenging approach to undertake new policies, which are monetary by their nature, but are unconventional regarding the instruments, which the leading global central banks use, and the operating goals, which they want to achieve.

On the basis of the above analysis, we can assume that the knowledge management constitutes a purposeful process of identifying, creating, transferring and exchanging various innovative and knowledge inventions, which are implemented in the right place and at the right time to influence any action, measure or decision of each organization. This opinion is close to, but differs in some way from that of Servin (2005,p. 3). According to a group of authors, a major business-oriented Gartner Group, knowledge management promotes an integrated approach of identification, capturing, retrieving, exchanging and evaluation of the information assets 
of the organization. These information assets may include databases, documents, policies, rules and procedures, as well as the not captured, unshared knowledge and experience, stored in the heads of individual employees.

Finally, we can summarize that the knowledge management in the field of unconventional monetary policy can be identified in two perspectives: first, organizational, and second, instrumental.

First, from organizational perspective the knowledge management in the field of unconventional monetary policy can be seen as a process of creating, capturing, retrieving, transferring and exchanging various innovative and knowledge inventions, and using knowledge and informationto enhance the central banks' overall performance. This is aimed to enhance the central banks' credibility for the general public, and to help them to achieve their broad macroeconomic goals such as the price stability and sustainable economic growth. Moreover, this can lead to a clear and profound understanding of the objectives, decisions and effects from the unconventional monetary policy measures in the public and the society. Central banks are seemed as knowledge organizations, as well as knowledge transferors for the type of their monetary policies.

Second, from instrumental perspective the knowledge management should be seen from the point of view of the formulation and implementation of the innovative unconventional monetary policy by the central banks. Using the definition of Allee (2003, p. 64) that the "knowledge is a state of knowing", we can define that the knowledge management is a set of all kinds of the central banks'information assets, knowledge, understanding and experience for the goals, strategies, measures, tools, programs, transmission mechanisms and effects of the innovative unconventional monetary policy for the economy.

\section{EFFECTS FROM THE INNOVATIVE UNCONVENTIONAL MONETARY POLICY FOR THE DEVELOPED AND EMERGING ECONOMIES}

During the recent years, the unconventional monetary policies have become more popular and are commonly used by the world's leading central banks. This is because during the periods of extreme economic crisis, the traditional monetary policy tools may no longer be effective in achieving their goals (Bini Smaghi, 2009).

The unconventional monetary policies launched by the central banks of the United States, Japan and the Eurozone have two main objectives. The first is to restore the normal functioning of the financial markets after the global financial crisis' severe consequences. The second objective is to provide additional accommodative monetary policy with close to zero or negative nominal interest rates. Those two objectives are closely related, because their overall objective is to provide price and macroeconomic stability.

In a broader extent the non-standard monetary policy measures have succeeded their internal objectives and have been especially effective during the global financial crisis. As a whole the functioning of the financial markets has been restored, and the tail risks decreased significantly. Also the unconventional monetary policies have led to a decline in the interest rates (yields) on long-term bonds and in some cases - in credit spreads and exchange rates. There has been a favorable impact on the economic growth and the price stability, although the evidence about this is not so clear, given the long time lags and the fact that the unconventional measures are still in place. The unconventional monetary policy measures of the central banks of the United States, the Euro area and Japan has generated different effects on the rest of the world.

Having in mind that the monetary policy is a major factor for the interest rate changes, in this section an empirical study on the dynamics and relationships between the key policy interest rates and the long-term government bond yields in a wide range of countries is made. The surveyed countries are 24 in total, including: (1) 18 Euro area member states (excluding Estonia) - Austria, Belgium, Germany, Greece, Ireland, Spain, Italy, Cyprus, Latvia, Lithuania, Luxembourg, Malta, the Netherlands, Portugal, Slovakia, Slovenia, Finland and France. Only for Estonia no econometric model is developed because of the lack of relevant statistical data. (2) 6 large developed and developing economies - the United States, Japan, China, Russian Federation, Brazil and Turkey. The reviewed period for all surveyed countries is from January 2010 to December 2016, by using monthly data (end of each month), including totally 84 observations. Econometric models for each observed country are constructed. 


\subsection{Research Methodology}

The empirical study on the effects of the global leading central banks' unconventional monetary policies on the Euro area members, the United States, Japan, China, Russian Federation, Brazil and Turkey, is made by using econometric modeling. The statistical software EViews, version 10, is applied. More precisely, the impact of the key policy interest rates on the central government long-term bond yields of the investigated totally 24 countries is assessed empirically. The reason behind is the fact that the policy of lowering the key interest rates close to zero and even below zero is the main tool of the unconventional monetary policies of the Fed, BoJ and the ECB. The constructed linear econometric models have the following analytical view:

where:

$$
Y_{t}=\beta_{0}+\beta_{1} X_{t}+\beta_{2} t+\varepsilon_{t}+\varepsilon_{t-1}+\varepsilon_{t-2},
$$

$Y_{t}$ (dependent variable) is the yield on long-term central government bonds (10-year Treasury bonds yields); $X_{t}$ is the independent variable for the base interest rate; $t$ is for the time as another independent variable; $\varepsilon_{t}$ is for the residual component.

The long-term government bond yield is measured by the 10 -year Treasury bonds (i.e. central government bonds issued by all countries under review). The 10-year maturity is selected because it is a widespread benchmark used in financial markets. As concerns the econometric models for the Euro area member states as a factor variable $X_{t}$ is used the Euro OverNight Index Average (EONIA). EONIA is the effective overnight reference rate for the euro. It is computed as a weighted average of all overnight unsecured lending transactions in the interbank market, undertaken in the European Union (EU) and European Free Trade Association (EFTA) countries. Nowadays, the German government bonds (German bund) are the benchmark for the bonds issued by the other countries in the Euro area (Castellani and dos Santos, 2005, p. 6).

As concerns the other large economies examined in the study, the following reference rates are used for factor variables: for the United States - the FED's Federal funds rate which is the interest rate at which depository institutions trade federal funds (balances held at Federal Reserve Banks) with each other overnight ${ }^{1}$; for Japan - the key short-term interest rate of the BoJ; for China - the base interest rate of the People's Bank of China (PBC) (or Chinese central bank's interest rate); for the Russian Federation - the short-term key interest rate of the Central Bank of the Russian Federation (CBR), which is the one-week repo rate; for Brazil - the Banco Central de Brazil (BACEN) SELIC rate or the Brazilian central bank's target interest rate - an average of the interbank interest rates which are charged for the trade in government securities with a maturity of 1 day; for Turkey - the one week repo auction rate of the Central Bank of Turkey.

All econometric models are constructed by using the Linear least squares regression method ARMA Generalized Least Squares (Gauss-Newton). The adequacy of each developed econometric model is confirmed by using the F-test-Prob (F-statistic). An model is adequate when F-test-Prob (F-statistic) $<\alpha$, where $\alpha=0,05$. Also, the explanatory power of each model is demonstrated (as measured by $\mathrm{R}^{2}$ ). It shows how many percents of the government bond yield changes can be explained by the changes in the two examined factors - the base interest rate and the time. The detailed results from all developed econometric models for the 24 analyzed countries are presented in Tables 1 and 2 in the Appendix.

\subsection{Results from the Empirical Study}

\subsubsection{Results for the Euro Area Member States}

The aggregated results from the constructed econometric models for the Euro area member states demonstrate that between $94 \%$ and $98 \%$ of the changes in the long-term government bond yields in the Euro area countries can be explained by the changes in the EONIA rate and over time. At EONIA fixed values, the long-term central government bond yields of the Euro area member states would fall in the range of $-0,13$ to $-0,050$ percentage points (p.p.) on a monthly basis, ceteris paribus. During the period 2010-2016 the time had no statistically significant impact on the central government bond yields of Greece, Cyprus, Spain, Ireland,

\footnotetext{
${ }^{1}$ In some other studies, for example of Castellani and dos Santos $(2005$, p. 8) the Libor is used instead of the Fed federal funds rate.
} 
Portugal and Slovenia - countries among the hardest hit by the Eurozone debt crisis, with limited access to the international capital markets, especially Greece, for example. Table 1 demonstrates that the EONIA and the time are not statistically significant for $1 / 3$ of the cases. There are several main reasons behind this conclusion:

- Fragmentation in the European interbank money market during the observed period. As Mayordomo et al. (2015) argue, the fragmentation in the interbank market has been, on average, higher in the peripheral Euro area countries than in the core ones and it has increased particularly during periods of financial stress. Among the most significant factors that contributed to the high fragmentation levels observed are the global factors such as: financing costs and counterparty risk; and country-specific factors such as the debt-to-GDP ratio, the economic sentiment, and the banking sector openness. The general credit risk experienced in the Euro area and the higher credit risk related to the early stages of the European sovereign debt crisis have also influenced the interbank money market (Christensen and Ejsing, 2013, p. 55).It is concluded that an open and small banking sector and a good economic sentiment can lead to a lower fragmentation in the European interbank market (Mayordomo et al., 2015).

- Low interest rate pass-through in the Euro area. According to Horvath (2018, p. 331), financial market fragmentation in the euro area reduced the effectiveness of monetary policy transmission. Bank interest rates in some Euro area countries did not fall following the interest rate cuts by the ECB. This low interest rate pass-through was primarily caused by the increase in mark-ups due to higher perceived risks. Although the financial market fragmentation decreased after 2012, there are still some warning signs, such as the significant decrease in turnover in money markets or the cross-country divergence in housing prices in the Euro area (Horvath, 2018, p. 331). On the other side, many authors provide evidences that the ECB's unconventional monetary policy has helped to reduce the financial market fragmentation in the Euro area (Al-Eyd and Berkmen, 2013; Szczerbowicz, 2015; Andrade et al., 2016).

- Excess liquidity in the Euro area, thus limiting the need of credit institutions to attract short-term funds through the interbank money market, leading to a lower demand in the interbank market and lower levels of EONIA. The introduction of the fixed-rate full-allotment procedure - as a prominent unconventional measure of the ECB - has made the dynamics of the money market growingly dependent on the time-varying level of excess liquidity in the Euro area (Beaupain and Durré, 2016).

- QE, implemented by the ECB- traditionally based on purchases of long-term central government bonds of the Euro area member states in the secondary market - over time have had a significant impact on the government bond yields towards their reduction. The QE has twofold effects: first, sovereign yields serve as a benchmark for pricing riskier privately issued securities. When long-term central government bonds are purchased, the yields on privately issued securities are expected to decline in parallel with those on government bonds. Second, if long-term interest rates begin to fall, this can stimulate longer-term investments and hence, aggregate demand, thereby supporting the price stability in the Euro area.

\subsubsection{Results for the United States, Japan, China, Russian Federation, Brazil and Turkey}

The results from the constructed econometric models for the Unites States and Japan demonstrate that respectively $90 \%$ and $98 \%$ of the changes in the long-term central government bond yields in both countries can be explained by the changes in their base interest rates and over time. For the United States and Japan, an increase in their key policy interest rates by 1 p.p. would lead to a change in the yields on their long-term central government bonds by $-0,016$ and $+0,71$ p.p., respectively, ceteris paribus. The US Federal funds rate and the BoJ's key short-term interest rate do not have statically significant impact on the long-term central government bond yields in the two countries. Historically, the US government bonds (10-year maturity) reached an all-time high of 15.82 in September 1981 and a record low of 1.36 in July 2016. As concerns Japan, historically, the Japanese 10-year government bonds reached an all-time high of 7.59 in May 1984 and a record low of -0.29 in July 2016.

For China and the Russian Federation, 91\% of the changes in their long-term central government bond yields can be explained by the changes in their base interest rates and over time. The key policy rate of the People's Bank of China does not have statistically significant impact on the Chinese long-term government bond yields. An increase by 1 p.p. in the PBC's base interest rate would increase the yield on the Chinese long-term central government bonds by 0,30 p.p., ceteris paribus. The time has no statistically significant 
impact on the 10-year government bond yield in China. Historically, the Chinese 10-year government bonds reached an all-time high of 4.85 in November 2013 and a record low of 2.51 in December 2008. Gros (2016, p. 7) argues that China has been a drag on the global interest rates. The combination of a rise in savings and large current account surpluses caused by China's export-oriented growth model led to an extensive outflow of funds. These went mainly into advanced economies where they dragged down real interest rates, enabled by Chinese financial market integration.

The estimations show that the short-term key interest rate of the Central Bank of the Russian Federation has statistically significant impact on the long-term central government bond yields. An increase in the CBR's reference (one-week repo) rate by 1 p.p. would lead to an increase in the Russian 10-year government bond yields by 0,433 , ceteris paribus. Historically, the Russian 10 -year government bonds reached an all-time high of 16.33 in January 2001 and a record low of 6.26 in July 2007.

The results from the constructed econometric models for Turkey and Brazil demonstrate that respectively $98,5 \%$ and $87 \%$ of the changes in the long-term central government bond yields in both countries can be explained by the changes in their base interest rates and over time. As concerns the case of Turkey, the reference (one week repo) rate of the Central Bank of Turkey and the time do not have statically significant impact on the Turkish long-term government bond yields. Historically, the Turkish government bonds (10-years) reached an all-time high of 21.53 in August 2018 and a record low of 6.02 in May 2013.

The econometric estimations for Brazil demonstrate that the central bank's reference rate (BACEN SELIC rate) has statically significant impact on the Brazilian long-term government bond yields. An increase in the BACEN SELIC rate by 1 p.p. would increase the Brazilian 10-year government bond yields by 0,36 p.p., ceteris paribus. Historically, the Brazilian10-year government bonds reached an all time high of 17.91 in October 2008 and a record low of 9.11 in January 2013.

\section{CONCLUSION}

Knowledge for the innovative unconventional monetary policy should be perceived as a strategic asset that needs to be enhanced and transferred to the general public. Two perspectives of the knowledge management in the field of unconventional policy are identified: first, as a process of creating, capturing, retrieving, transferring and exchanging various innovative and knowledge inventions, and using knowledge and information to enhance the central banks' overall performance. This is aimed to enhance the central banks' credibility for the general public, and to help them to achieve their broad macroeconomic goals such as the price stability and sustainable economic growth. The public and the society might also better understand the objectives, decisions, measures, programs and effects from the unconventional monetary policy. Central banks are seemed as knowledge organizations, as well as knowledge transferors for their monetary policies to the general public. Second, from instrumental perspective the knowledge management is seen from the point of view of the formulation and implementation of the innovative unconventional monetary policy. It is identified as a set of central banks' information assets, knowledge, understanding and experience for the goals, strategies, measures, tools, programs, transmission mechanisms and effects of the innovative unconventional monetary policy. The econometric study on the effects of the global leading central banks' unconventional monetary policies on the Euro area member states, the United States, Japan, China, Russia, Brazil and Turkey, demonstrate that between $90 \%$ and $98,5 \%$ of the changes in the long-term government bond yields in all surveyed countries can be explained by the changes in the base interest rates and over time. Looking forward, in the foreseeable future the leading global central banks is expected to continue their unconventional monetary policy course if the economic circumstances remain unchanged or deteriorate. Another important issue to look for is whether if the central banks normalize their monetary policy, it will not lead to a new financial or economic crisis.

\section{ACKNOWLEDGEMENT}

The paper is prepared as a part of the research activities under the project "The innovative unconventional monetary policy of the central banks and its effects on the developed and emerging countries, with an emphasis on Bulgaria" (Project No. DN15/10, 2017), financed by the Bulgarian National Science Fund. 


\section{REFERENCES}

Al-Eyd, A., Berkmen, S. P., 2013. Fragmentation and Monetary Policy in the Euro Area. IMF Working Paper, No. 13-208, International Monetary Fund, Washington, D.C., USA.

Allee, V., 2003. The Future of Knowledge; Increasing Prosperity through Value Networks. Butter font-Heinemann, Amsterdam, the Netherlands.

Andrade, P., Breckenfelder, J., De Fiore, F., Karadi, P., Tristani, O., 2016. The ECB's Asset Purchase Programme: An Early Assessment. Working Paper Series, No. 1956, European Central Bank, Frankfurt am Main.

Bassi, L.J., 1997. "Harnessing the power of intellectual capital", Training and Development, Vol. 51, No. 12, pp. 25-30.

Beaupain, R., Durré, A., 2016. Excess liquidity and the money market in the euro area. Journal of Macroeconomics, Vol. 47, Part A, March, pp. 33-44.

Bini Smaghi, L., 2009. Conventional and unconventional monetary policy. Member of the Executive Board of the European Central Bank, Keynote lecture at the International Center for Money and Banking Studies (ICMB), Geneva, Switzerland, 28 April, European Central Bank.

Blackler, F., 1995. Knowledge, Knowledge Work and Organizations: An Overview and Interpretation. Organizational Studies, Vol. 16, Issue 6, November, pp. 1021-1046.

Castellani, M., Dos Santos, E. A. 2005. Forecasting Long-Term Government Bond Yields: An Application of Statistical and AI Models.

Christensen, N. H., Ejsing, J. W., 2013. Decomposing Government Yield Spreads into Credit and Liquidity Components. Money Review, $1^{\text {st }}$ Quarter, Part 2, pp. 45-69.

Cyert, R. M., March, J. G., 1963. A Behavioural Theory of the Firm, Englewood Cliffs, Prentice Hall, New Jersey, USA.

Devenport, T.H., Prusac, L., 1998. Knowledge Management. Harvard Business School Press, USA.

Eggertsson, G., Juelsrud, R., Wold, E.G., 2018. Monetary policy with negative interest rates. VOX CEPR Policy Portal, 31 January.

Foss, K., Foss, N. J. (2006). Simon on problem solving: implications for new organizational forms. Intellectual Journal of Learning and Intellectual Capital, Vol. 3(4), pp. 339-356.

Gros, D., 2016. Ultra-low or Negative Yields on Euro-Area Long-term Bonds: Causes and Implications for Monetary Policy. CEPS Working Document, No. 426, September.

Hicks, R.C., Galup, S. D., Dattero, R., 2006. The Five Tier Knowledge Management Transformation Matrix. Journal of Knowledge Management, Vol. 10, No. 1, pp. 19-31.

Horvath, R., 2018. Financial market fragmentation and monetary transmission in the euro area: what do we know?.Journal of Economic Policy Reform, Vol. 21, No. 4, pp. 319-334.

Joia, L.A., 2000. Measuring intangible corporate assets: Linking business strategy with intellectual capital. Journal of Intellectual Capital, Vol. 1, No. 1.

Massave, P. A. J., 2015. A Framework for critical evaluation of strategies for value creation within knowledge-based organizations. Coventry University, July.

Mayordomo, S., Abascal, M., Alonso, T., Rodriguez-Moreno, M., 2015. Fragmentation in the European interbank market: Measures, determinants, and policy solutions. Journal of Financial Stability, Vol. 16, February, pp. 1-12.

Nonaka, I., Takeuchi, H., 1995. The Knowledge-Creating Company - How Japanese Companies Create the Dynamics of Innovation. Oxford University Press, UK.

Servin, G., 2005. ABC of Knowledge Management. NHS National Library for Health: Knowledge Management Specialist Library, July.

Szczerbowicz, U., 2015. The ECB Unconventional Monetary Policies: Have They Lowered Market Borrowing Costs for Banks and Governments?. International Journal of Central Banking, 11 (4), pp. 91-127. 


\section{APPENDIX}

Table 1. Results from the econometric modelling (ARMA Generalized Least Squares method) for the Euro area member states

\begin{tabular}{|c|c|c|c|c|c|c|c|c|}
\hline \multicolumn{9}{|c|}{ 1. Austria } \\
\hline Variable & Coefficient & Std. Error & t-Statistic & Prob. & R-squared & 0.980735 & Mean dependent var & 1.933929 \\
\hline $\mathrm{C}$ & 3.767695 & 0.245866 & 15.32418 & 0.0000 & $\begin{array}{l}\text { Adjusted R- } \\
\text { squared }\end{array}$ & 0.979759 & S.D. dependent var & 1.114057 \\
\hline EU_EONIA & -0.009095 & 0.231721 & -0.039248 & 0.9688 & S.E. of regression & 0.158496 & Akaike info criterion & -0.767015 \\
\hline $\mathrm{T}$ & -0.042758 & 0.004688 & -9.120191 & 0.0000 & Sum squared resid & 1.984557 & Schwarz criterion & -0.622324 \\
\hline $\mathrm{AR}(1)$ & 1.223886 & 0.104174 & 11.74853 & 0.0000 & Log likelihood & 37.21465 & $\begin{array}{l}\text { Hannan-Quinn } \\
\text { criter. }\end{array}$ & -0.708851 \\
\hline $\mathrm{AR}(2)$ & -0.396153 & 0.104389 & -3.794974 & 0.0003 & F-statistic & 1005.421 & Durbin-Watson stat & 2.049324 \\
\hline & & & & & Prob(F-statistic) & 0.000000 & & \\
\hline \multicolumn{9}{|c|}{ 2. Belgium } \\
\hline Variable & Coefficient & Std. Error & t-Statistic & Prob. & R-squared & 0.981501 & Mean dependent var & 2.305000 \\
\hline $\mathrm{C}$ & 4.266774 & 0.414007 & 10.30603 & 0.0000 & $\begin{array}{l}\text { Adjusted R- } \\
\text { squared }\end{array}$ & 0.980564 & S.D. dependent var & 1.333593 \\
\hline EU_EONIA & -0.014169 & 0.275688 & -0.051395 & 0.9591 & S.E. of regression & 0.185918 & Akaike info criterion & -0.441977 \\
\hline $\mathrm{T}$ & -0.046402 & 0.008045 & -5.767407 & 0.0000 & Sum squared resid & 2.730686 & Schwarz criterion & -0.297286 \\
\hline $\operatorname{AR}(1)$ & 1.270090 & 0.106652 & 11.90868 & 0.0000 & Log likelihood & 23.56304 & $\begin{array}{l}\text { Hannan-Quinn } \\
\text { criter. }\end{array}$ & -0.383812 \\
\hline $\mathrm{AR}(2)$ & -0.364457 & 0.105859 & -3.442840 & 0.0009 & F-statistic & 1047.879 & Durbin-Watson stat & 1.933694 \\
\hline & & & & & Prob(F-statistic) & 0.000000 & & \\
\hline \multicolumn{9}{|c|}{ 3. Cyprus } \\
\hline Variable & Coefficient & Std. Error & t-Statistic & Prob. & R-squared & 0.943302 & Mean dependent var & 5.456667 \\
\hline $\mathrm{C}$ & 5.125180 & 1.440039 & 3.559056 & 0.0006 & $\begin{array}{l}\text { Adjusted R- } \\
\text { squared }\end{array}$ & 0.941176 & S.D. dependent var & 1.249248 \\
\hline EU_EONIA & 0.404735 & 0.456951 & 0.885729 & 0.3784 & S.E. of regression & 0.302988 & Akaike info criterion & 0.533499 \\
\hline $\mathrm{T}$ & -0.009734 & 0.024261 & -0.401231 & 0.6893 & Sum squared resid & 7.344149 & Schwarz criterion & 0.649252 \\
\hline $\mathrm{AR}(1)$ & 0.977961 & 0.029085 & 33.62426 & 0.0000 & Log likelihood & -18.40694 & $\begin{array}{l}\text { Hannan-Quinn } \\
\text { criter. }\end{array}$ & 0.580030 \\
\hline & & & & & F-statistic & 443.6632 & Durbin-Watson stat & 1.732448 \\
\hline & & & & & Prob(F-statistic) & 0.000000 & & \\
\hline \multicolumn{9}{|c|}{ 4. Finland } \\
\hline Variable & Coefficient & Std. Error & t-Statistic & Prob. & R-squared & 0.979700 & Mean dependent var & 1.756905 \\
\hline $\mathrm{C}$ & 3.180007 & 0.225064 & 14.12937 & 0.0000 & $\begin{array}{l}\text { Adjusted R- } \\
\text { squared }\end{array}$ & 0.978672 & S.D. dependent var & 1.000496 \\
\hline EU_EONIA & 0.318967 & 0.215931 & 1.477170 & 0.1436 & S.E. of regression & 0.146113 & Akaike info criterion & -0.929946 \\
\hline $\mathrm{T}$ & -0.034428 & 0.004266 & -8.069578 & 0.0000 & Sum squared resid & 1.686568 & Schwarz criterion & -0.785254 \\
\hline $\mathrm{AR}(1)$ & 1.222582 & 0.104033 & 11.75181 & 0.0000 & Log likelihood & 44.05772 & $\begin{array}{l}\text { Hannan-Quinn } \\
\text { criter. }\end{array}$ & -0.871781 \\
\hline $\mathrm{AR}(2)$ & -0.400633 & 0.104878 & -3.819970 & 0.0003 & F-statistic & 953.1588 & Durbin-Watson stat & 1.985139 \\
\hline & & & & & Prob(F-statistic) & 0.000000 & & \\
\hline \multicolumn{9}{|c|}{ 5. France } \\
\hline Variable & Coefficient & Std. Error & t-Statistic & Prob. & R-squared & 0.979015 & Mean dependent var & 2.022143 \\
\hline $\mathrm{C}$ & 3.671175 & 0.259865 & 14.12726 & 0.0000 & $\begin{array}{l}\text { Adjusted R- } \\
\text { squared }\end{array}$ & 0.977670 & S.D. dependent var & 1.062460 \\
\hline EU_EONIA & 0.049775 & 0.228027 & 0.218284 & 0.8278 & S.E. of regression & 0.158765 & Akaike info criterion & -0.751322 \\
\hline $\mathrm{T}$ & -0.038828 & 0.004996 & -7.771239 & 0.0000 & Sum squared resid & 1.966093 & Schwarz criterion & -0.577692 \\
\hline $\mathrm{AR}(1)$ & 1.297867 & 0.112765 & 11.50953 & 0.0000 & Log likelihood & 37.55551 & $\begin{array}{l}\text { Hannan-Quinn } \\
\text { criter. }\end{array}$ & -0.681524 \\
\hline $\mathrm{AR}(2)$ & -0.577426 & 0.175481 & -3.290536 & 0.0015 & F-statistic & 727.8027 & Durbin-Watson stat & 1.941173 \\
\hline $\mathrm{AR}(3)$ & 0.129750 & 0.115803 & 1.120437 & 0.2660 & Prob(F-statistic) & 0.000000 & & \\
\hline \multicolumn{9}{|c|}{ 6. Germany } \\
\hline Variable & Coefficient & Std. Error & t-Statistic & Prob. & R-squared & 0.979231 & Mean dependent var & 1.452262 \\
\hline $\mathrm{C}$ & 2.861994 & 0.238495 & 12.00022 & 0.0000 & $\begin{array}{l}\text { Adjusted R- } \\
\text { squared }\end{array}$ & 0.978180 & S.D. dependent var & 0.975694 \\
\hline EU_EONIA & 0.278014 & 0.215649 & 1.289195 & 0.2011 & S.E. of regression & 0.144127 & Akaike info criterion & -0.955008 \\
\hline $\mathrm{T}$ & -0.033780 & 0.004543 & -7.435481 & 0.0000 & Sum squared resid & 1.641036 & Schwarz criterion & -0.810317 \\
\hline $\mathrm{AR}(1)$ & 1.272322 & 0.103103 & 12.34028 & 0.0000 & Log likelihood & 45.11034 & $\begin{array}{l}\text { Hannan-Quinn } \\
\text { criter. }\end{array}$ & -0.896843 \\
\hline $\mathrm{AR}(2)$ & -0.429568 & 0.104403 & -4.114507 & 0.0001 & F-statistic & 931.1929 & Durbin-Watson stat & 2.020540 \\
\hline & & & & & Prob(F-statistic) & 0.000000 & & \\
\hline \multicolumn{9}{|c|}{ 7. Greece } \\
\hline Variable & Coefficient & Std. Error & t-Statistic & Prob. & R-squared & 0.898574 & Mean dependent var & 11.78940 \\
\hline $\mathrm{C}$ & 10.80043 & 6.364789 & 1.696904 & 0.0938 & $\begin{array}{l}\text { Adjusted R- } \\
\text { squared }\end{array}$ & 0.891987 & S.D. dependent var & 5.664315 \\
\hline EU_EONIA & -1.063556 & 2.783776 & -0.382055 & 0.7035 & S.E. of regression & 1.861592 & Akaike info criterion & 4.191945 \\
\hline $\mathrm{T}$ & -0.021213 & 0.109899 & -0.193027 & 0.8474 & Sum squared resid & 266.8455 & Schwarz criterion & 4.366801 \\
\hline $\mathrm{AR}(1)$ & 1.091599 & 0.112482 & 9.704671 & 0.0000 & Log likelihood & -167.9657 & $\begin{array}{l}\text { Hannan-Quinn } \\
\text { criter. }\end{array}$ & 4.262192 \\
\hline
\end{tabular}




\begin{tabular}{|c|c|c|c|c|c|c|c|c|}
\hline $\mathrm{AR}(2)$ & -0.331318 & 0.163645 & $\begin{array}{l}-2.024614 \\
\end{array}$ & 0.0464 & F-statistic & 136.4341 & Durbin-Watson stat & 1.988414 \\
\hline $\mathrm{AR}(3)$ & 0.200566 & 0.112393 & 1.784498 & 0.0783 & Prob(F-statistic) & 0.000000 & & \\
\hline \multicolumn{9}{|c|}{ 8. Ireland } \\
\hline Variable & Coefficient & Std. Error & t-Statistic & Prob. & R-squared & 0.973644 & Mean dependent var & 4.226905 \\
\hline $\mathrm{C}$ & 6.597232 & 1.850356 & 3.565385 & 0.0006 & $\begin{array}{l}\text { Adjusted R- } \\
\text { squared }\end{array}$ & 0.972310 & S.D. dependent var & 3.065617 \\
\hline EU_EONIA & 0.392781 & 0.759539 & 0.517131 & 0.6065 & S.E. of regression & 0.510132 & Akaike info criterion & 1.582576 \\
\hline $\mathrm{T}$ & -0.066003 & 0.033791 & $\begin{array}{l}-1.953258 \\
\end{array}$ & 0.0543 & Sum squared resid & $\begin{array}{l}20.55858 \\
\end{array}$ & Schwarz criterion & 1.727268 \\
\hline $\mathrm{AR}(1)$ & 1.199474 & 0.110351 & 10.86967 & 0.0000 & Log likelihood & -61.46820 & $\begin{array}{l}\text { Hannan-Quinn } \\
\text { criter. }\end{array}$ & 1.640741 \\
\hline $\mathrm{AR}(2)$ & -0.243495 & 0.109252 & -2.228753 & 0.0287 & F-statistic & 729.6054 & Durbin-Watson stat & 2.015896 \\
\hline & & & & & Prob(F-statistic) & 0.000000 & & \\
\hline \multicolumn{9}{|c|}{ 9. Italy } \\
\hline Variable & Coefficient & Std. Error & t-Statistic & Prob. & R-squared & 0.970246 & Mean dependent var & 3.623452 \\
\hline $\mathrm{C}$ & 5.213737 & 1.097853 & 4.749029 & 0.0000 & $\begin{array}{l}\text { Adjusted R- } \\
\text { squared }\end{array}$ & 0.968740 & S.D. dependent var & 1.592844 \\
\hline EU_EONIA & -0.456967 & 0.420287 & -1.087275 & 0.2802 & S.E. of regression & 0.281625 & Akaike info criterion & 0.396247 \\
\hline $\mathrm{T}$ & -0.040361 & 0.019945 & -2.023580 & 0.0464 & Sum squared resid & 6.265677 & Schwarz criterion & 0.540938 \\
\hline $\mathrm{AR}(1)$ & 1.238692 & 0.109129 & 11.35067 & 0.0000 & Log likelihood & -11.64236 & $\begin{array}{l}\text { Hannan-Quinn } \\
\text { criter. }\end{array}$ & 0.454411 \\
\hline $\mathrm{AR}(2)$ & -0.278899 & 0.108183 & -2.578035 & 0.0118 & F-statistic & 644.0295 & Durbin-Watson stat & 1.997975 \\
\hline & & & & & Prob(F-statistic) & 0.000000 & & \\
\hline \multicolumn{9}{|c|}{ 10. Latvia } \\
\hline Variable & Coefficient & $\begin{array}{l}\text { Std. Error } \\
\end{array}$ & t-Statistic & Prob. & R-squared & 0.980696 & Mean dependent var & 4.022262 \\
\hline $\mathrm{C}$ & 9.871545 & 0.949570 & 10.39581 & 0.0000 & $\begin{array}{l}\text { Adjusted R- } \\
\text { squared }\end{array}$ & 0.979459 & S.D. dependent var & 3.228833 \\
\hline EU_EONIA & -0.753347 & 0.701557 & -1.073822 & 0.2862 & S.E. of regression & 0.462763 & Akaike info criterion & 1.629633 \\
\hline $\mathrm{T}$ & -0.132704 & 0.018393 & -7.214750 & 0.0000 & Sum squared resid & 16.70368 & Schwarz criterion & 1.803263 \\
\hline $\mathrm{AR}(1)$ & 1.175715 & 0.228666 & 5.141617 & 0.0000 & Log likelihood & -62.44459 & $\begin{array}{l}\text { Hannan-Quinn } \\
\text { criter. }\end{array}$ & 1.699431 \\
\hline $\mathrm{AR}(2)$ & -0.203924 & 0.166476 & -1.224948 & 0.2243 & F-statistic & 792.5307 & Durbin-Watson stat & 1.796435 \\
\hline $\mathrm{AR}(11)$ & -0.132004 & 0.128282 & -1.029018 & 0.3067 & Prob(F-statistic) & 0.000000 & & \\
\hline \multicolumn{9}{|c|}{ 11. Lithuania } \\
\hline Variable & Coefficient & Std. Error & t-Statistic & Prob. & R-squared & 0.978093 & Mean dependent var & 3.494405 \\
\hline $\mathrm{C}$ & 6.878421 & 0.433061 & 15.88327 & 0.0000 & $\begin{array}{l}\text { Adjusted R- } \\
\text { squared }\end{array}$ & 0.976984 & S.D. dependent var & 1.799533 \\
\hline EU_EONIA & -0.154843 & 0.391166 & -0.395850 & 0.6933 & S.E. of regression & 0.273008 & Akaike info criterion & 0.322071 \\
\hline $\mathrm{T}$ & -0.077393 & 0.008279 & $\begin{array}{l}-9.348208 \\
\end{array}$ & 0.0000 & Sum squared resid & 5.888124 & Schwarz criterion & 0.466763 \\
\hline $\mathrm{AR}(1)$ & 1.269108 & 0.108147 & 11.73499 & 0.0000 & Log likelihood & -8.526997 & $\begin{array}{l}\text { Hannan-Quinn } \\
\text { criter. }\end{array}$ & 0.380236 \\
\hline $\mathrm{AR}(2)$ & -0.438345 & 0.103581 & -4.231924 & 0.0001 & F-statistic & 881.7959 & Durbin-Watson stat & 2.178496 \\
\hline & & & & & Prob(F-statistic) & 0.000000 & & \\
\hline \multicolumn{9}{|c|}{ 12. Luxembourg } \\
\hline Variable & Coefficient & $\begin{array}{l}\text { Std. Error } \\
\end{array}$ & t-Statistic & Prob. & R-squared & 0.981935 & Mean dependent var & 1.675357 \\
\hline $\mathrm{C}$ & 3.390923 & 0.270813 & 12.52125 & 0.0000 & $\begin{array}{l}\text { Adjusted R- } \\
\text { squared }\end{array}$ & 0.981021 & S.D. dependent var & 1.108863 \\
\hline EU_EONIA & 0.167674 & 0.227524 & 0.736951 & 0.4633 & S.E. of regression & 0.152764 & Akaike info criterion & -0.838340 \\
\hline $\mathrm{T}$ & -0.040185 & 0.005195 & -7.735816 & 0.0000 & Sum squared resid & 1.843603 & Schwarz criterion & -0.693648 \\
\hline $\mathrm{AR}(1)$ & 1.250882 & 0.105598 & 11.84565 & 0.0000 & Log likelihood & 40.21028 & $\begin{array}{l}\text { Hannan-Quinn } \\
\text { criter. }\end{array}$ & -0.780175 \\
\hline $\mathrm{AR}(2)$ & -0.387294 & 0.106057 & -3.651733 & 0.0005 & F-statistic & 1073.535 & Durbin-Watson stat & 2.026990 \\
\hline & & & & & Prob(F-statistic) & 0.000000 & & \\
\hline \multicolumn{9}{|c|}{ 13. Malta } \\
\hline Variable & Coefficient & $\begin{array}{l}\text { Std. Error } \\
\end{array}$ & t-Statistic & Prob. & R-squared & $\begin{array}{l}0.992307 \\
\end{array}$ & Mean dependent var & 3.021429 \\
\hline $\mathrm{C}$ & 5.006613 & 0.424439 & 11.79583 & 0.0000 & $\begin{array}{l}\text { Adjusted R- } \\
\text { squared }\end{array}$ & 0.991917 & S.D. dependent var & 1.332538 \\
\hline EU_EONIA & -0.083403 & 0.175748 & -0.474562 & 0.6364 & S.E. of regression & 0.119800 & Akaike info criterion & -1.313364 \\
\hline $\mathrm{T}$ & -0.048397 & 0.007929 & -6.103654 & 0.0000 & Sum squared resid & 1.133808 & Schwarz criterion & -1.168673 \\
\hline $\mathrm{AR}(1)$ & 1.306499 & 0.106427 & 12.27600 & 0.0000 & Log likelihood & 60.16130 & $\begin{array}{l}\text { Hannan-Quinn } \\
\text { criter. }\end{array}$ & -1.255199 \\
\hline $\mathrm{AR}(2)$ & -0.354381 & 0.105661 & -3.353946 & 0.0012 & F-statistic & 2547.481 & Durbin-Watson stat & 1.932219 \\
\hline & & & & & Prob(F-statistic) & 0.000000 & & \\
\hline \multicolumn{9}{|c|}{ 14. Netherlands } \\
\hline Variable & Coefficient & Std. Error & t-Statistic & Prob. & R-squared & 0.981142 & Mean dependent var & 1.759167 \\
\hline $\mathrm{C}$ & 3.170704 & 0.227164 & 13.95779 & 0.0000 & $\begin{array}{l}\text { Adjusted R- } \\
\text { squared }\end{array}$ & 0.980187 & S.D. dependent var & 1.018856 \\
\hline EU_EONIA & 0.368140 & 0.209951 & 1.753458 & 0.0834 & S.E. of regression & 0.143413 & Akaike info criterion & -0.965622 \\
\hline$T$ & -0.034371 & 0.004330 & -7.937507 & 0.0000 & Sum squared resid & 1.624826 & Schwarz criterion & -0.820930 \\
\hline $\mathrm{AR}(1)$ & 1.263380 & 0.102313 & 12.34821 & 0.0000 & Log likelihood & 45.55611 & $\begin{array}{l}\text { Hannan-Quinn } \\
\text { criter. }\end{array}$ & -0.907457 \\
\hline \multirow[t]{2}{*}{$\mathrm{AR}(2)$} & -0.431560 & 0.103131 & -4.184577 & 0.0001 & F-statistic & 1027.533 & Durbin-Watson stat & 2.012135 \\
\hline & & & & & Prob(F-statistic) & 0.000000 & & \\
\hline
\end{tabular}




\begin{tabular}{|c|c|c|c|c|c|c|c|c|}
\hline \multicolumn{9}{|c|}{ 15. Portugal } \\
\hline Variable & Coefficient & Std. Error & t-Statistic & Prob. & R-squared & 0.972170 & Mean dependent var & 5.975476 \\
\hline $\mathrm{C}$ & 5.269971 & 3.386223 & 1.556298 & 0.1236 & $\begin{array}{l}\text { Adjusted R- } \\
\text { squared }\end{array}$ & 0.970761 & S.D. dependent var & 3.282188 \\
\hline EU_EONIA & 0.420766 & 0.836451 & 0.503038 & 0.6163 & S.E. of regression & 0.561233 & Akaike info criterion & 1.783450 \\
\hline $\mathrm{T}$ & -0.009673 & 0.052725 & -0.183465 & 0.8549 & Sum squared resid & 24.88362 & Schwarz criterion & 1.928142 \\
\hline $\mathrm{AR}(1)$ & 1.162667 & 0.111327 & 10.44374 & 0.0000 & Log likelihood & -69.90491 & $\begin{array}{l}\text { Hannan-Quinn } \\
\text { criter. }\end{array}$ & 1.841615 \\
\hline $\mathrm{AR}(2)$ & -0.179603 & 0.111158 & $\begin{array}{l}-1.615744 \\
\end{array}$ & 0.1101 & F-statistic & 689.9232 & Durbin-Watson stat & 2.089644 \\
\hline & & & & & Prob(F-statistic) & 0.000000 & & \\
\hline & & & & & Inverted AR Roots & .98 & .18 & \\
\hline \multicolumn{9}{|c|}{ 16. Slovakia } \\
\hline Variable & Coefficient & Std. Error & t-Statistic & Prob. & R-squared & 0.980563 & Mean dependent var & 2.794167 \\
\hline $\mathrm{C}$ & 4.837969 & 0.698401 & 6.927208 & 0.0000 & $\begin{array}{l}\text { Adjusted R- } \\
\text { squared }\end{array}$ & 0.979579 & S.D. dependent var & 1.579845 \\
\hline EU_EONIA & -0.135226 & 0.337273 & -0.400941 & 0.6895 & S.E. of regression & 0.225765 & Akaike info criterion & -0.049428 \\
\hline $\mathrm{T}$ & -0.048351 & 0.013367 & -3.617112 & 0.0005 & Sum squared resid & 4.026610 & Schwarz criterion & 0.095263 \\
\hline $\mathrm{AR}(1)$ & 1.257488 & 0.110144 & 11.41681 & 0.0000 & Log likelihood & 7.075991 & $\begin{array}{l}\text { Hannan-Quinn } \\
\text { criter. }\end{array}$ & 0.008736 \\
\hline $\mathrm{AR}(2)$ & -0.316247 & 0.108997 & -2.901442 & 0.0048 & F-statistic & 996.3451 & Durbin-Watson stat & 1.873568 \\
\hline & & & & & Prob(F-statistic) & 0.000000 & & \\
\hline \multicolumn{9}{|c|}{ 17. Slovenia } \\
\hline Variable & Coefficient & Std. Error & t-Statistic & Prob. & R-squared & 0.966061 & Mean dependent var & 3.792500 \\
\hline $\mathrm{C}$ & 5.618975 & 1.394445 & 4.029542 & 0.0001 & $\begin{array}{l}\text { Adjusted R- } \\
\text { squared }\end{array}$ & 0.964342 & S.D. dependent var & 1.841355 \\
\hline EU_EONIA & -0.628195 & 0.512847 & -1.224917 & 0.2242 & S.E. of regression & 0.347708 & Akaike info criterion & 0.820293 \\
\hline $\mathrm{T}$ & -0.048512 & 0.025838 & -1.877570 & 0.0641 & Sum squared resid & 9.551159 & Schwarz criterion & 0.964984 \\
\hline & & & & & & & Hannan-Quinn & \\
\hline $\mathrm{AR}(1)$ & 1.331955 & 0.106855 & 12.46511 & 0.0000 & Log likelihood & -29.45230 & criter. & 0.878457 \\
\hline $\mathrm{AR}(2)$ & -0.372071 & 0.106302 & -3.500132 & 0.0008 & F-statistic & 562.1711 & Durbin-Watson stat & 2.021489 \\
\hline & & & & & Prob(F-statistic) & 0.000000 & & \\
\hline \multicolumn{9}{|c|}{ 18. Spain } \\
\hline Variable & Coefficient & Std. Error & t-Statistic & Prob. & R-squared & 0.973061 & Mean dependent var & 3.707381 \\
\hline $\mathrm{C}$ & 5.169412 & 346 & 009 & 0.0001 & $\begin{array}{l}\text { Adjusted R- } \\
\text { squared }\end{array}$ & 0.971697 & S.D. dependent var & 1.700917 \\
\hline EU_EONIA & -0.390713 & 0.425252 & -0.918781 & 0.3610 & S.E. of regression & 0.286155 & Akaike info criterion & 0.429641 \\
\hline$T$ & -0.041507 & 0.021721 & $\begin{array}{l}-1.910901 \\
\end{array}$ & 0.0596 & Sum squared resid & 6.468909 & Schwarz criterion & 0.574333 \\
\hline $\mathrm{AR}(1)$ & 1.197975 & 0.110459 & 10.84541 & 0.0000 & Log likelihood & -13.04494 & $\begin{array}{l}\text { Hannan-Quinn } \\
\text { criter. }\end{array}$ & 0.487806 \\
\hline \multirow[t]{2}{*}{$\mathrm{AR}(2)$} & -0.230302 & 0.109862 & -2.096285 & 0.0393 & F-statistic & 713.3789 & Durbin-Watson stat & 1.985046 \\
\hline & & & & & Prob(F-statistic) & 0.000000 & & \\
\hline
\end{tabular}

Source: own estimations.

Table 2. Results from the econometric modelling (ARMA Generalized Least Squares method) for the United States, Japan, China, Russia, Brazil and Turkey

\begin{tabular}{|c|c|c|c|c|c|c|c|c|}
\hline \multicolumn{9}{|c|}{ 1. United States } \\
\hline Coefficient & Std. Error & t-Statistic & Prob. & & R-squared & 0.977893 & Mean dependent var & 0.679167 \\
\hline $\mathrm{C}$ & 2.984800 & 0.391658 & 7.620942 & 0.0000 & $\begin{array}{l}\text { Adjusted R- } \\
\text { squared }\end{array}$ & 0.976774 & S.D. dependent var & 0.416871 \\
\hline UNITED_STATES_IR & 0.487759 & 0.528706 & 0.922553 & 0.3590 & $\begin{array}{l}\text { S.E. of } \\
\text { regression }\end{array}$ & 0.063531 & Akaike info criterion & -2.601929 \\
\hline $\mathrm{T}$ & -0.015584 & 0.007815 & -1.994149 & 0.0496 & $\begin{array}{l}\text { Sum squared } \\
\text { resid }\end{array}$ & 0.318862 & Schwarz criterion & -2.457237 \\
\hline $\mathrm{AR}(1)$ & 1.235662 & 0.112727 & 10.96152 & 0.0000 & Log likelihood & 114.2810 & Hannan-Quinn criter. & -2.543764 \\
\hline $\operatorname{AR}(2)$ & -0.324873 & 0.111450 & -2.914957 & 0.0046 & F-statistic & 873.6477 & Durbin-Watson stat & 1.708672 \\
\hline & & & & & Prob(F-statistic) & 0.000000 & & \\
\hline \multicolumn{9}{|c|}{ 2. Japan } \\
\hline Coefficient & Std. Error & t-Statistic & Prob. & & R-squared & 0.977893 & Mean dependent var & 0.679167 \\
\hline $\mathrm{C}$ & 1.266037 & 0.043307 & 29.23395 & 0.0000 & $\begin{array}{l}\text { Adjusted R- } \\
\text { squared }\end{array}$ & 0.976774 & S.D. dependent var & 0.416871 \\
\hline JAPAN_IR & 0.710946 & 0.238965 & 2.975100 & 0.0039 & $\begin{array}{l}\text { S.E. of } \\
\text { regression }\end{array}$ & 0.063531 & Akaike info criterion & -2.601929 \\
\hline $\mathrm{T}$ & -0.014950 & 0.000672 & -22.24634 & 0.0000 & $\begin{array}{l}\text { Sum squared } \\
\text { resid }\end{array}$ & 0.318862 & Schwarz criterion & -2.457237 \\
\hline $\mathrm{AR}(1)$ & 0.684974 & 0.080321 & 8.527942 & 0.0000 & Log likelihood & 114.2810 & Hannan-Quinn criter. & -2.543764 \\
\hline $\mathrm{AR}(6)$ & -0.227966 & 0.082559 & -2.761261 & 0.0072 & F-statistic & 873.6477 & Durbin-Watson stat & 1.708672 \\
\hline & & & & & Prob(F-statistic) & 0.000000 & & \\
\hline \multicolumn{9}{|c|}{ 3. China } \\
\hline Coefficient & Std. Error & t-Statistic & Prob. & & R-squared & 0.913248 & Mean dependent var & 3.582095 \\
\hline $\mathrm{C}$ & 1.954832 & 0.832178 & 2.349056 & 0.0213 & $\begin{array}{l}\text { Adjusted R- } \\
\text { squared }\end{array}$ & 0.909995 & S.D. dependent var & 0.446700 \\
\hline CHINA_IR & 0.303938 & 0.128932 & 2.357354 & 0.0208 & $\begin{array}{l}\text { S.E. of } \\
\text { regression }\end{array}$ & 0.134014 & Akaike info criterion & -1.113406 \\
\hline
\end{tabular}




\begin{tabular}{|c|c|c|c|c|c|c|c|c|}
\hline $\mathrm{T}$ & -0.001904 & 0.005531 & -0.344346 & 0.7315 & $\begin{array}{l}\text { Sum squared } \\
\text { resid }\end{array}$ & 1.436780 & Schwarz criterion & -0.997653 \\
\hline $\mathrm{AR}(1)$ & 0.917059 & 0.045723 & 20.05671 & 0.0000 & Log likelihood & 50.76305 & Hannan-Quinn criter. & -1.066874 \\
\hline & & & & & F-statistic & 280.7220 & Durbin-Watson stat & 1.772614 \\
\hline & & & & & Prob(F-statistic) & 0.000000 & & \\
\hline \multicolumn{9}{|c|}{ 4. Russian Federation } \\
\hline Coefficient & Std. Error & t-Statistic & Prob. & & R-squared & 0.917672 & Mean dependent var & 8.631167 \\
\hline $\mathrm{C}$ & 4.128781 & 0.881722 & 4.682632 & 0.0000 & $\begin{array}{l}\text { Adjusted R- } \\
\text { squared }\end{array}$ & 0.912395 & S.D. dependent var & 1.581144 \\
\hline RUSSIA_IR & 0.433471 & 0.057667 & 7.516773 & 0.0000 & $\begin{array}{l}\text { S.E. of } \\
\text { regression }\end{array}$ & 0.467989 & Akaike info criterion & 1.407728 \\
\hline $\mathrm{T}$ & 0.008922 & 0.014867 & 0.600099 & 0.5502 & $\begin{array}{l}\text { Sum squared } \\
\text { resid }\end{array}$ & 17.08306 & Schwarz criterion & 1.581358 \\
\hline $\operatorname{AR}(1)$ & 1.006176 & 0.111793 & 9.000322 & 0.0000 & Log likelihood & 53.12458 & Hannan-Quinn criter. & 1.477526 \\
\hline $\mathrm{AR}(2)$ & -0.366635 & 0.154030 & -2.380282 & 0.0197 & F-statistic & 173.8871 & Durbin-Watson stat & 1.937552 \\
\hline $\mathrm{AR}(3)$ & 0.253532 & 0.111650 & 2.270787 & 0.0259 & Prob(F-statistic) & 0.000000 & & \\
\hline \multicolumn{9}{|c|}{ 5. Brazil } \\
\hline Coefficient & Std. Error & t-Statistic & Prob. & & R-squared & 0.885473 & Mean dependent var & 12.13001 \\
\hline $\mathrm{C}$ & 8.244819 & 1.661876 & 4.961152 & 0.0000 & $\begin{array}{l}\text { Adjusted R- } \\
\text { squared }\end{array}$ & 0.879674 & S.D. dependent var & 1.564837 \\
\hline BRAZIL_IR & 0.364611 & 0.176132 & 2.070104 & 0.0417 & $\begin{array}{l}\text { S.E. of } \\
\text { regression }\end{array}$ & 0.542811 & Akaike info criterion & 1.698416 \\
\hline $\mathrm{T}$ & -0.003161 & 0.013773 & -0.229519 & 0.8191 & $\begin{array}{l}\text { Sum squared } \\
\text { resid }\end{array}$ & 23.27686 & Schwarz criterion & 1.843108 \\
\hline $\mathrm{AR}(1)$ & 0.916326 & 0.057260 & 16.00290 & 0.0000 & Log likelihood & 66.33349 & Hannan-Quinn criter. & 1.756581 \\
\hline $\mathrm{AR}(7)$ & -0.147943 & 0.060382 & -2.450110 & 0.0165 & F-statistic & 152.6984 & Durbin-Watson stat & 1.916658 \\
\hline & & & & & Prob(F-statistic) & 0.000000 & & \\
\hline \multicolumn{9}{|c|}{ 6.Turkey } \\
\hline Coefficient & Std. Error & t-Statistic & Prob. & & R-squared & 0.867832 & Mean dependent var & 9.111429 \\
\hline $\mathrm{C}$ & 9.448781 & 1.094937 & 8.629523 & 0.0000 & $\begin{array}{l}\text { Adjusted R- } \\
\text { squared }\end{array}$ & 0.859360 & S.D. dependent var & 1.127865 \\
\hline TURKEY_IR & -0.031409 & 0.068861 & -0.456123 & 0.6496 & $\begin{array}{l}\text { S.E. of } \\
\text { regression }\end{array}$ & 0.422972 & Akaike info criterion & 1.215992 \\
\hline $\mathrm{T}$ & 0.004596 & 0.019675 & 0.233605 & 0.8159 & $\begin{array}{l}\text { Sum squared } \\
\text { resid }\end{array}$ & 13.95462 & Schwarz criterion & 1.389622 \\
\hline $\mathrm{AR}(1)$ & 1.393704 & 0.114077 & 12.21726 & 0.0000 & Log likelihood & 45.07167 & Hannan-Quinn criter. & 1.285790 \\
\hline $\mathrm{AR}(2)$ & -0.690721 & 0.180180 & -3.833509 & 0.0003 & F-statistic & 102.4318 & Durbin-Watson stat & 1.976362 \\
\hline $\mathrm{AR}(3)$ & 0.224187 & 0.114365 & 1.960282 & 0.0535 & Prob(F-statistic) & 0.000000 & & \\
\hline
\end{tabular}

Source: own estimations. 